\title{
User Response to and Knowledge about an Online Catalog
}

\section{David Steinberg and Paul Metz}

\section{BACKGROUND}

As online catalogs proliferate in libraries, complementing card catalogs with the ultimate prospect of substituting for them in many cases, the library profession has recognized the importance of designing systems that are easily used and that reflect patron needs and expectations. The expression "user friendly," an overnight cliché, refers to one aspect of this concern. However, the cognitive problems of software design-the use of mnemonic commands, graceful transitions between screens, and plentiful "help" or tutorial features-represent only one aspect of the system design challenge that will provide users with what they want and expect. It is equally important to provide access by the approaches users want to employ.

The task of determining this is not easy, for users and librarians do not always speak the same language. For example, when users tell us that they want subject access, it is easy for librarians to narrow the problem to the $6 x x$ fields of the MARC record and to make plans for Boolean or keyword approaches to this information. But as Lee Jones has argued, what patrons seem to want is an approach to books by their "real" subjects, defined much more broadly. ${ }^{1}$ To a patron, the term hydraulic represents a subject and should provide an access path regardless of whether it occurs in subject, corporate author, or title fields. Clearly, the art of listening to our patrons requires great sensitivity and awareness.

Research on user expectations and demands is now conducted regularly and offers the promise that systems designers will be able to work from a realistic appraisal of the user and the user's preferred strategies. Studies by Moore and by Norden and Lawrence have contributed significantly to what we know by documenting the popularity of online catalogs, the desirability of subject searching, and the perception by users that insufficient recall, rather than the lack of precision in searches, is still a problem. ${ }^{2}$ Most recently, OCLC, with the support of the Council on Library Resources, conducted a number of concurrent studies of online public access systems (OPACs) in a variety of library settings. These studies add even more to what we know about the users of automated catalogs, though there is much still to learn.

\section{METHODOLOGY}

The present study reports the perceptions of users of another OPAC, the Virginia Tech Library System (VTLS), in response to a survey administered in spring of 1983. Used at Virginia Tech since 1980, and now at some thirty other libraries as well, VTLS is accessible by all author, title, subject, and added entry fields, as well as by call number, item number, and a full range of bibliographic control numbers, including OCLC number. Because it is an integrated system that encompasses circulation control, information on item availability is provided. Records have been input for all cataloging since 1980 and for all materials that have circulated since 1975 , when a short-record precursor of VTLS was introduced. For serials, holdings are described. For records entered between 1975 and 1980, only limited information is available, and there is no subject access.

David Steinberg is a doctoral candidate in education and Paul Metz is user services librarian, both at the Virginia Polytechnic Institute and State University, Blacksburg. 
Commands are mnemonic ("Al" plus search argument for author searching, " $\mathrm{T} /$ " for title, etc.) as are screen flows, including "NS" and "PS" for next and previous screens. The design principles and search features of VTLS have been more fully described by Uluakar, Pierce, and Chachra. ${ }^{3}$

The current study evolved from a pilot study conducted at Virginia Tech in 1982 by John Ulmschneider, then an intern at the Library of Medicine. Ulmschneider had drawn a number of his questionnaire items from the CLR/OCLC instrument. His research instrument was modified by the deletion of a small number of items and the addition of a short battery of questions designed to assess user knowledge of the system. This portion of the instrument was intended to help discover the problems of user education the library needed to address and to identify those forms of access that users expect to find in an online catalog and that a truly useroriented system would attempt to provide.

The sample group for the study comprised eighty-five system users. The sample was chosen by the senior author, who was stationed near two of the high-traffic computer catalog terminals situated between the card catalog and general reference desk. Questionnaires were also completed by patrons using other terminals in the main library, and in the branch library for the College of Veterinary Medicine. Individuals were asked to complete a questionnaire after finishing a search. All but four subjects were willing to respond, yielding a response rate of 95.5 percent. All eight of the university's colleges were represented in the sample. The sample population consisted of forty-seven undergraduate students, twenty-three graduate students, seven faculty members, four members of the university staff, and four nonuniversity patrons.

\section{FINDINGS}

In many ways the findings replicate results obtained elsewhere and increase the likelihood that various OPAC studies may be generalized for other settings. As in other studies, most patrons (58.8 per- cent) learned to use the system from printed instructions; the next most frequent sources of information were library staff (14.1 percent) and the help feature (10.6 percent). As in other studies, most patrons were extremely satisfied with the system, as 78.8 percent considered their searches to have been very or somewhat successful and 81.2 percent considered the system easier to use than the card cata$\log$. This preference for the online catalog over the card catalog was most pronounced in searching for journal titles or for books by personal authors. That 50.6 percent found the computer catalog easier for journal searches, while only 7.1 percent preferred the card catalog, may be due to an aversion to searching through the large number of cards frequently encountered in card catalogs for the works of corporate authors or for periodicals with common titles.

The findings also support previous research on the popularity of subject searching. Patrons were asked what they knew

DISORDERED MATERIALS: SCIENCE AND TECHNOLOGY Selected Papers by S.R.Ovshinsky

Edited by: David Adler

Professor of Electrical Engineering Massachusetts Institute of Technology

Published on the occasion of Stan Ovshinsky's 60th birthday, this selection of over 35 of his papers from 1968 to 1981 covers much of his work in amorphous materials ranging from switching and memory to energy conversion applications such as amorphous alloy photovoltaics. This book is relevant not only to those who wish to understand the basics of amorphous materials but also to those interested in the development of new synthetic materials.

1982, 296 pp., Cloth. ISBN 0-910331-00-6

US\$30.00

Amorphous Institute Press 1050 East Square Lake Road Bloomfield Hills, Michigan 48013. U.S.A. 
before they initiated their searches and what they had entered. In each case, subjects were ranked first, followed by title, author, and call number. The preference for title searching over author searching is consistent with Norden and Lawrence's findings, even though they report that users of card catalogs prefer the author approach. According to Norden and Lawrence, users tend to bring greater knowledge of titles than they do of authors to the catalog, but are discouraged by the difficulties of title searching in card catalogs. ${ }^{4}$ The great popularity of subject searching has been attested to in all previous studies of online catalogs, even though subject searches were found to be infrequent in Lipetz' classic study of the use of card catalogs. ${ }^{5}$ In respect, it is likely that the Lipetz study may have been misinterpreted by many as an indication of lack of desire for subject access, rather than the difficulty of obtaining subject access. The popularity of the subject approach to materials in online catalogs probably reflects the ease of searching but also-and more ominously-unfounded optimism about subject searching, a point to which we will return.

Respondents were also asked a battery of questions about what they were looking for in their most recent search. Again, the desire to obtain materials on a given subject was clearly paramount, followed by the desire to check on the availability of materials. The results of this part of the questionnaire are displayed in table 1 . It should be noted that most patrons answered yes to several questions, indicating multiple goals in searching, or a definition of the term "most recent search," which referred more to a search session than to a specific bibliographic inquiry. The Virginia Tech and State University libraries furnish a periodicals notebook that provides call numbers by author and title in a simple layout; the availability of this tool may have caused less searching than might be found in another periodicals setting.

The short quiz about the system included at the beginning of the questionnaire represents the new feature that this study introduces to the literature on online catalogs. In order to prevent guess- work by respondents accustomed to outwitting multiple-choice tests, a "don't know" option was provided for each question. Questions asked about the system are reproduced in table 2 , along with the distribution of responses. The correct response to each item is in italics. For the first item two responses were considered correct because while there are item records for about 50 percent of the library's volumes, volumes represented either by item records or by serials holdings records constitute closer to 75 percent of the collection.

\section{TABLE 1}

\section{PURPOSE OF MOST RECENT SEARCH}

\begin{tabular}{lc}
\hline \hline Purpose & Percent Reporting \\
\hline $\begin{array}{c}\text { "Find the call number of a spe- } \\
\text { cific book" }\end{array}$ & 49.4 \\
"Find the call number of a spe- \\
$\begin{array}{c}\text { cific journal or magazine" } \\
\text { "Find what back issues of a } \\
\begin{array}{l}\text { specific [journal] or maga- } \\
\text { zine the library had" }\end{array}\end{array}$ \\
$\begin{array}{l}\text { "Find works by a specific au- } \\
\text { thor" }\end{array}$ & 12.9 \\
"See if a book was checked \\
$\begin{array}{l}\text { out or on reserve" } \\
\text { "Find a book on a specific sub- } \\
\text { ject" }\end{array}$
\end{tabular}

$N=85$ for all items.

The word joumal was inadvertently omitted from the third item.

In some respects, the responses to the quiz about VTLS features revealed a level of understanding that is probably no worse than would be found if patrons' perceptions of the card catalog were assessed. More than 80 percent of patrons show some understanding of how author and title searches are formulated. Nearly all know that the system can indicate whether books are available (not surprisingly, since this was the second-mostsought type of information), and 71.8 percent know that periodical holdings information may also be accessed.

Serious public misconceptions are apparent from those items addressing system coverage and the utility and means of subject searching. More than one-third ( 34.1 percent) of the respondents had no idea what percentage of the collection was represented in VTLS, and another 9.4 per- 


\section{TABLE 2}

\section{PATRON RESPONSES TO VTLS QUIZ}

1. The percentage of the Library's titles available through the computer catalog is:
a. $100 \%$
b. $75 \%$
c. $50 \%$
d. $25 \%$
e. DK

(3.5\% of respondents)

$(43.5 \%)$

$(13.0 \%)$

$(5.9 \%)$

$(34.1 \%)$

2. If a book has ever been checked out, it is more likely to be in the computer catalog than if it has never been checked out.
a. True
b. False
c. DK
$(57.6 \%)$
$(11.8 \%)$
$(30.6 \%)$
3. The computer catalog was:
a. Developed at Virginia Tech and is complete
$b$. Developed at Virginia Tech and is still being improved
c. Purchased, and is complete
d. Purchased, and is being improved
e. DK
$(1.2 \%)$
$(40.0 \%)$

4. The computer catalog can tell me what volumes or years of a periodical the library has.
a. True
b. False
c. DK
$(71.8 \%$
$(9.4 \%)$

5. The computer catalog will tell me whether or not a book is in use.
a. True
b. False
$(94.1 \%)$
$(4.7 \%)$
c. DK

complete title.
a. True
b. False
c. DK
$(10.6 \%)$
$(85.9 \%)$
$(3.5 \%)$

7. The more of an author's name I enter into the computer catalog, the more I narrow my search to get just the author I want.
a. True
b. False
c. DK
(10.6\%)
d. Missing

8. All of the books in the computer catalog can be found through a subject approach.
a. True
b. False
c. DK
(32.9\%)
$(41.2 \%)$
(25.9\%)

9. It is possible to search the computer catalog by using subject terms other than the Library of Congress subject headings used in the card catalog.
a. True
b. False
c. DK
$(42.4 \%)$

$N=85$ for all items.

cent guessed wrong. Despite an active program of bibliographic instruction for freshmen and select other groups, disclaimers about subject searching in all printed instructions, and the cautions of reference librarians assisting users, nearly one-third of users believe that all materials in the system are accessible by subject, while only 41.2 percent know positively that this is not true. Worse yet, only $\mathbf{2 8 . 2}$ percent are aware that subject searching is possible only by the use of the same terms represented in the card catalog. That such misconceptions translate into practice is shown by the analysis: forty-five patrons reported that they had searched by subject, whereas only twenty-two had used terms from the Library of Congress Subject Headings.

The public's perceptions about subject searching seem to represent the epitome of wishful thinking. Eager to find information by subject, patrons rashly assume that if this search approach is offered, materials must be available by following it. Norden and Lawrence also found that subject searching at Ohio State became very popular as soon as it was introduced, 
despite soft-pedaling by librarians aware of its limitations. ${ }^{6}$

It is not difficult to extract policy implications from these data. First, they demonstrate the magnitude of the usereducation task by showing that even where very active programs exist, serious misconceptions can exist. The damage may not be so severe as long as dual systems are maintained (even the current sample of VTLS users reported that they used the card catalog somewhat more than the automated system). However, damage can become greater if card catalogs are closed or frozen. A second policy implication is that if patrons are so intent on subject searching that they become prey to optimistic delusions about its utility, wise librarians and system designers will be equally eager to provide both data and access points to make these perceptions realistic. Perhaps it is better to quash a happy delusion than to encourage it, but better still to make it true.

\section{REFERENCES}

1. Keith W. Russell, ed., Subject Access: Report of a Meeting Sponsored by the Council on Library Resources (Washington, D.C.: Council on Library Resources, 1982), p.7.

2. Carole Weiss Moore, "User Reactions to Online Catalogs: An Exploratory Study," College \& Research Libraries 42: 295-302 (July 1981); and David J. Norden and Gail Herndon Lawrence, "Public Terminal Use in an Online Catalog: Some Preliminary Results," College \& Research Libraries 42: 308-16 (July 1981).

3. Tamer Uluakar, Anton R. Pierce, and Vinod Chachra, "Design Principles for a Comprehensive Library System," Journal of Library Automation 14, no.2: 78-89 (June 1981).

4. Norden and Lawrence, "Public Terminal Use," p.315.

5. Ben-Ami Lipetz, "Catalog Use in a Large Research Library," Library Quarterly 42: 129-39 (Jan. 1972).

6. Norden and Lawrence, "Public Terminal Use," p.314.

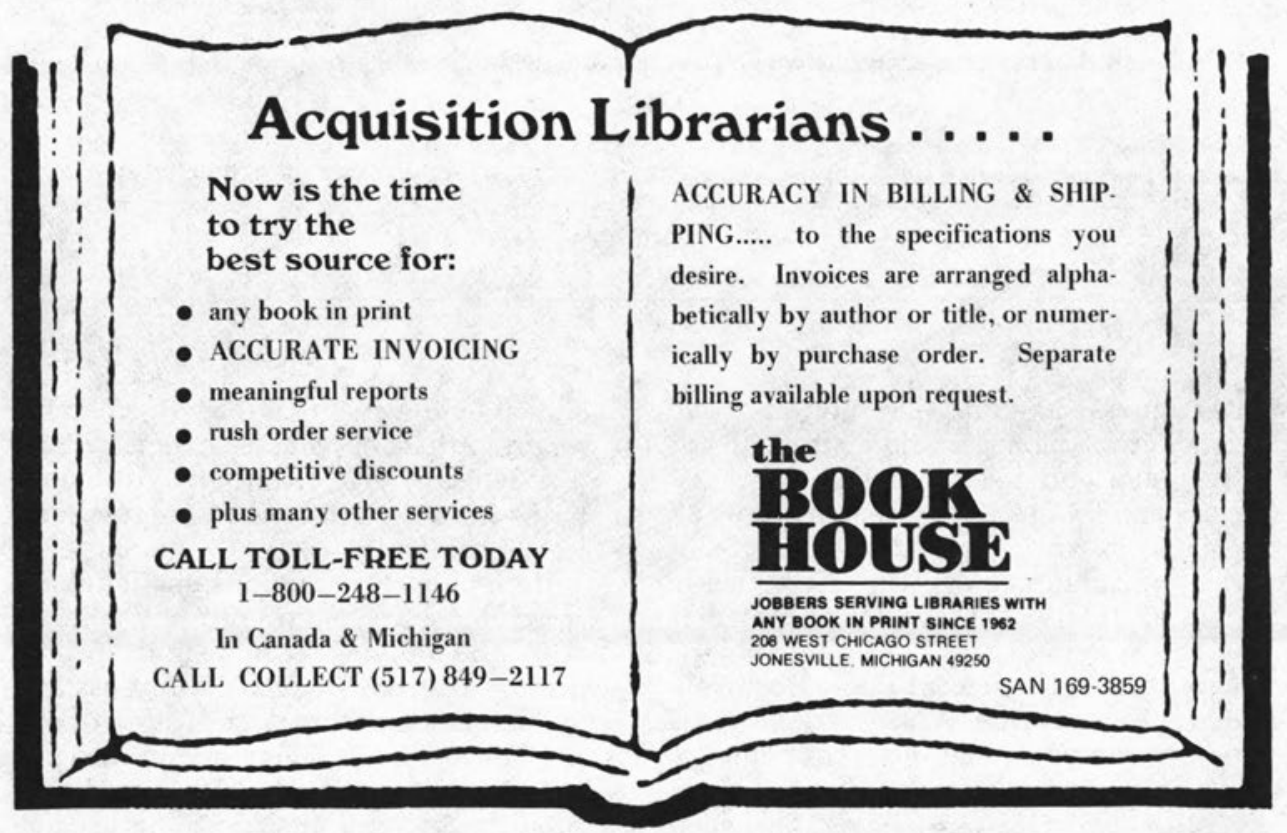

